\title{
Replacement of Animal Fat by Canola Oil in Chicken Meatball
}

http://dx.doi.org/10.1590/1806-9061-2019-1013

-Author(s)

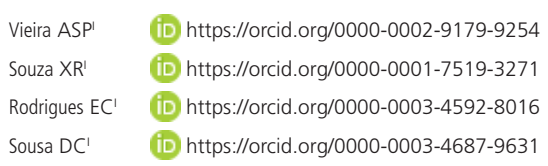

Instituto Federal do Mato Grosso (IFMT).

\section{-Mail Address}

Corresponding author e-mail address Xisto Rodrigues de Souza

IFMT, Programa de Pós-Graduação em Ciência e Tecnologia de Alimentos. Av. Juliano Costa Marques, s/n - Bela Vista Cuiabá - MT. CEP 78050-560.

Phone: 0086037167756317

Email: asplazza@gmail.com

\section{EKeywords}

Chicken product, centesimal composition, shelf life, sensory acceptance, vegetable oil.

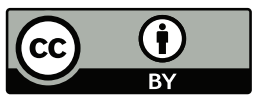

Submitted: 08/February/2019 Approved: 21/June/2019

\section{ABSTRACT}

This work aimed to develop chicken meatballs with five levels of animal fat replacement by canola oil and to evaluate the product's behavior during 120 days of storage. For that, analyzes were performed in the centesimal composition, fatty acid profile, shelf life and sensory parameters. The centesimal composition of the product did not present significant difference $(p>0.05)$ between the treatments. However, canola oil addition improved the lipid profile, atherogenic and thrombogenic indexes, and the ratios of PUFAs/SFAs (0.91 to 1.61) and n6/n3 (12.63 to 3.74$)$ in the products. Animal fat replacement and storage time also reduced meatballs $\mathrm{Aw}$ and $\mathrm{pH}$. No differences in texture between treatments were detected after 30 days of storage. The lipid oxidation presented by mean values of TBARs ranged from 0.71 and $1.35 \mathrm{mg}$ MDA $/ \mathrm{kg}$, indicating the onset and the regression of lipid oxidation. The color parameters exhibited a spectrum towards the luminous yellow color, predominant in both chicken meat and canola oil. The results of this study indicate that the substitution of animal fat by canola oil is promising in the production of meat products with good acceptability (70\%) during the sensory analysis.

\section{INTRODUCTION}

In recent years, there has been a greater demand for low-fat meat products because of concerns about the development of syndromes such as obesity and heart disease associated with high fat intake, especially saturated fat (Afshari et al., 2016). Therefore, the food industry has been looking to develop foods, among them meat products, with low fat contents. However, developing low-fat meat products has been a huge challenge as lipids have an important role in the texture, juiciness, and taste of the food. Besides, lipids have important physiological functions in the organism as a source of energy and essential fatty acids (EFAs), and as carriers of liposoluble vitamins (Özvural \& Vural, 2008; Monteiro et al., 2017).

Several studies have been proposed to develop meat products with lower levels of saturated fatty acids (SFAs) by replacing animal fat with vegetable oils. In general, SFAs has been considered a risk factor for cardiovascular disease (CVD) and, on the other hand, studies have shown that polyunsaturated fatty acids (PUFAs) intake was inversely associated with CVD risk (Monteiro et al. 2017, Barbut \& Marangoni, 2018). For this reason, different studies suggest that PUFAs improve the lipid profile of foods (Yunes et al., 2013; Afshari et al., 2016; Monteiro et al., 2017).

Therefore, the substitution of animal fat by vegetal oil contributes to the elaboration of products with better PUFAs/SFAs profiles, better ratio $\mathrm{n} 6 / \mathrm{n} 3$ and reduction of atherogenic index (Al) and thrombogenic 
index ( $\mathrm{TI})$ when compared to traditional products. Among the VOs, canola oil is the one with the lowest concentration of SFAs (6\%), in addition to a high concentration of MUFAs (58\%) and PUFAs (36\%). The PUFAs in $\mathrm{CO}$ are represented mostly by linoleic acid $(21 \%)$, alpha-linolenic acid (10\%) and oleic acid $(60 \%)$. Studies have found that these EFAs should be regularly ingested in the diet, with a lower $n 6 / n 3$ ratio, as a means to prevent and control inflammatory diseases such as bowel disease (Monteiro et al. 2017; Visentainer et al., 2015).

The objective of this work was to evaluate the effects of the substitution of animal fat at different levels by canola oil in chicken meatballs, considering the sensorial, physicochemical characteristics, lipid profile and storage stability.

\section{MATERIAL AND METHODS}

All the experimental procedures described here were previously approved by the Research Committee of Ethics of the Federal Institute of the State of Mato Grosso (protocol \# 2483360). Also, before the sensory panel was performed, a microbiological assay was developed to ensure that the meatballs met the microbiological standards recommended by the International Commission on Microbiological Specifications for Foods (1986) and the National Sanitary Surveillance Agency (ANVISA), through Resolution No. 12 (BRAZIL, 2001).

\section{Chicken meatballs preparation}

For the processing of chicken meatballs, a basal mass without addition of animal fat and canola oil, which are the variable components of the experiment (Table 1), was prepared. The plant oil used was the commercially available canola oils Liza, from the industry Cargil SA, having citric acid as the antioxidant.

Grinded chicken breast was put in a mixer with soy protein previously hydrated with water for 30 minutes. After 2 minutes of mixing, the other ingredients were incorporated and the dough was homogenized for further 5 minutes in the mixer.

After that, the basal mass was divided into five homogenous portions and subdivided into three replicates for the replacement of the chicken fat by canola oil in the proportions of $0 \%, 25,50,75$ and $100 \%$ (Table 1). Then, $30 \mathrm{~g}$ meatballs were manually cast, frozen at a temperature of $-25^{\circ} \mathrm{C}$ in ultra-freezer, packed in polyethylene bags, identified by treatment and stored in a vertical freezer at $-18^{\circ} \mathrm{C}$ for future analysis.
Table 1 - Ingredient composition of chicken meatballs with different levels of animal fat replacement by canola oil.

\begin{tabular}{lccccc}
\hline \multirow{2}{*}{ Fixed ingredients } & \multicolumn{5}{c}{ Canola oil } \\
\cline { 2 - 6 } & $0 \%$ & $25 \%$ & $50 \%$ & $75 \%$ & $100 \%$ \\
\hline chickenbreast & 68.90 & 68.90 & 68.90 & 68.90 & 68.90 \\
Water & 16.75 & 16.75 & 16.75 & 16.75 & 16.75 \\
breadcrumbs & 4.75 & 4.75 & 4.75 & 4.75 & 4.75 \\
texturedsoy proteín & 3.00 & 3.00 & 3.00 & 3.00 & 3.00 \\
\hline Salt & 1.23 & 1.23 & 1.23 & 1.23 & 1.23 \\
isolatedsoy proteín & 1.00 & 1.00 & 1.00 & 1.00 & 1.00 \\
\hline driedonion & 0.97 & 0.97 & 0.97 & 0.97 & 0.97 \\
dehydrated parsley & 0.19 & 0.19 & 0.19 & 0.19 & 0.19 \\
\hline tripoli phosphaeo & 0.15 & 0.15 & 0.15 & 0.15 & 0.15 \\
Sugar & 0.08 & 0.08 & 0.08 & 0.08 & 0.08 \\
monossodium glutamate & 0.07 & 0.07 & 0.07 & 0.07 & 0.07 \\
garlic aroma & 0.07 & 0.07 & 0.07 & 0.07 & 0.07 \\
\hline sodium erythorbate & 0.04 & 0.04 & 0.04 & 0.04 & 0.04 \\
\hline Variableingredients & & & & & \\
\hline chickenfat & 2.80 & 2.10 & 1.40 & 0.70 & 0.00 \\
\hline canola oil & 0.00 & 0.70 & 1.40 & 2.10 & 2.80 \\
\hline Total & 100 & 100 & 100 & 100 & 100 \\
\hline
\end{tabular}

Immediately after the preparation, 80 meatballs of each replicate were randomly selected for sensory, centesimal, microbiological, physicochemical and fatty acid profile analyses. The other meatballs remained frozen for repetition of the same physicochemical analyzes after 30,60, 90 and 120 days.

For that, meatballs were previously thawed at $4^{\circ} \mathrm{C}$ in BOD incubators. When roasted products were assessed, samples were baked at $150^{\circ} \mathrm{C}$ until reaching the central temperature of $71^{\circ} \mathrm{C}$, according to the methodology adapted from AMSA (2016).

\section{Analysis of the centesimal composition}

For the analysis of centesimal composition, performed only at time 0 , raw and roasted meatballs were used. Samples were previously homogenized in a multiprocessor and analyzed in duplicate for moisture, ashes, protein, lipids and carbohydrates according to procedures established by AOAC (2012). Final results were expressed as percentage of the sample's weight.

\section{Analysis of fatty acid profile}

The fatty acid profile of meatballs was exclusively assessed at time 0 , using raw and roasted samples. Each sample was subjected to lipid cold extraction according to the methodology originally described by Folch, Lees and Stanley (1957). Then, aliquots were destined to gas chromagraph determination as established by Hartman and Lago (1973).

Based on the fatty acid profile, meatballs' atherogenic (Al) and thrombogenic (TI) indices were calculated following Ulbricht \& Southgate (1991) equations, where: 
$\mathrm{Al}=((\mathrm{C} 12: 0)+4(\mathrm{C} 14: 0)+(\mathrm{C} 16: 0)) /((\mathrm{n} 6)+(\mathrm{n} 3)+($ (IMUFAs $))$

$\mathrm{TI}=((C 14: 0)+(C 16: 0)+(C 18: 0)) /([0.5($ LMUFAs $)+0.5(\mathrm{n} 6)+3(\mathrm{n} 3)+(\mathrm{n} 3 / \mathrm{n} 6))$

All analyzes were performed in duplicate and expressed as percentage of the sample's weight.

\section{Shelf life analysis}

Shelf life analyzes were performed during the storage time of $0,30,60,90$ and 120 days. For this, raw meatballs were submitted to water activity (Aw), $\mathrm{pH}$ and Tbars analysis. Also, roasted samples were analyzed for texture and color. Aw determination was performed by the dew point technique using the AQUALAB 4TE equipment. Samples' $\mathrm{pH}$ was determined using an insertion electrode coupled to a portable digital potentiometer (Meat $\mathrm{pH}$ meter $\mathrm{HI}$ 99163). The Tbars was obtained according to the method described by Raharjo, Sofos \& Schmidt (1992) and the values obtained were expressed in milligrams of malonaldehyde per kilogram of samples (mg maloaldehyde / kg sample).

For the texture analysis, samples of roasted meatballs were accommodated in the TA.XT.PLUS texturometer, with a Warner Bratzler probe coupled, calibrated for a cutting speed of $2 \mathrm{~mm} / \mathrm{s}$, a return speed of $5 \mathrm{~mm} / \mathrm{s}$, a sensitivity of $0.250 \mathrm{~N}$ and unit in $\mathrm{kg} / \mathrm{cm} 2$. The objective color was analyzed using the Minolta CM-700D with the D65 illuminator and $10^{\circ}$ viewing angle by the CIE $L^{*} a * b *$ color system. Three readings were taken at the center of the samples of roasted meatballs (AMSA, 2016).

\section{Sensory analysis}

A sensory panel was performed at time 0 using roasted meatballs. A total of 80 untrained judges evaluated the sensory characteristics of smell, color, overall appearance, texture and taste in a hedonic scale (1 - I highly disliked 9 - I liked it very much), and the preference index as recommended in the official methodology of the Adolfo Lutz Institute (Zenebon, Pascuet, Tiglea, 2008).

\section{Statistical analysis}

Data of centesimal composition were analyzed in a completely randomized design (CRD), with 5 treatments (canola oil \%) and 3 replications of one meatball each. Data of fatty acid profile were analyzed in a factorial design with 10 treatments and 3 replications of one meatball each. Factors were presentation mode (raw and roasted) and canola oil \% (0, 25, 50, 75 and 100\%). Data of sensory analyses were analyzed in a CRD, with 5 treatments (canola oil\%) and 80 replications of one judge each. Finally, data of shelf life analyses were analyzed in a factorial design with 25 treatments and 3 replications of one meatball each. Factors were storage time $(0,30,60,90$ and 120 days) and canola oil \% (0, $25,50,75$ and $100 \%$ ).

All data were initially tested for homogeneity of variances and normality of the studentized residues. After these assumptions were met, they were submitted to analysis of variance and, in case of significant differences, treatment means were separated by the Tukey test. The variables of the sensory test and $\mathrm{pH}$ were considered non-parametric, thus being submitted to a non-parametric analysis of variance (Wilcoxon test) and, in the case of significant differences, treatment means were separated by the Dunn test. In all stages, significance was set at $5 \%(p \leq 0.05)$.

\section{RESULTS AND DISCUSSION}

\section{Centesimal composition}

There was no significant difference between raw and roasted meatballs at different replacement levels (Table 2). This study corroborates with other studies

Table 2 - Centesimal composition of raw and roasted chicken meatballs with different levels of animal fat replacement by canola oil.

\begin{tabular}{|c|c|c|c|c|c|c|c|}
\hline \multirow{2}{*}{ Item (\% of original matter) } & \multicolumn{5}{|c|}{ Canola oil } & \multirow{2}{*}{ SEM } & \multirow{2}{*}{$p$ values } \\
\hline & $0 \%$ & $25 \%$ & $50 \%$ & $75 \%$ & $100 \%$ & & \\
\hline \multicolumn{8}{|l|}{ Raw meatballs } \\
\hline carbohydrate & 8.65 & 8.70 & 7.71 & 8.11 & 8.70 & 0.54 & 0.98 \\
\hline Ashes & 2.51 & 2.46 & 2.49 & 2.52 & 2.52 & 0.01 & 0.07 \\
\hline Lipids & 3.15 & 3.20 & 3.32 & 3.62 & 3.57 & 0.07 & 0.14 \\
\hline protein & 17.08 & 17.00 & 18.40 & 17.90 & 16.70 & 0.53 & 0.88 \\
\hline moisture & 68.60 & 68.63 & 68.08 & 67.85 & 68.51 & 0.16 & 0.46 \\
\hline \multicolumn{8}{|l|}{ Roasted meatballs } \\
\hline carbohydrate & 7.52 & 8.57 & 8.66 & 9.53 & 11.34 & 0.54 & 0.23 \\
\hline ashes & 3.43 & 3.43 & 3.44 & 3.49 & 3.58 & 0.02 & 0.20 \\
\hline lipids & 3.57 & 3.08 & 2.69 & 2.88 & 3.28 & 0.12 & 0.11 \\
\hline protein & 25.69 & 24.36 & 25.06 & 24.82 & 23.75 & 0.34 & 0.51 \\
\hline moisture & 59.79 & 60.55 & 60.15 & 59.27 & 58.04 & 0.32 & 0.08 \\
\hline
\end{tabular}


that show the adequacy of substitution of animal fat by canola oil, regardless of presentation, raw or roasted.

The same was observed by Monteiro et al. (2017) and Backes et al. (2013) where they demonstrated that canola oil is an excellent substitute for animal fat, maintaining the product's centesimal characteristics unchanged.

\section{Fatty acid profile}

The fatty acid profile of treatments is shown in table 3. From the 11 fatty acids detected, the 16:0, 18:1 and $18: 2$ acids showed the highest concentrations. The same acids were detected by Monteiro et al. (2017) in the partial replacement of animal fat by canola oil.

The addition of canola oil in meatballs reduced total SFAs concentration and their individual porcentages. Afshari, R (2016); Yunes et al. (2013) and Monteiro et al. (2017) also found a reduction in the SFAs by replacing animal fat by vegetable oils in meat products. These findings can be explained by the fact that canola oil contains low levels of SFAs (6\%), high levels of MUFAs (58\%) and moderate levels of PUFAs
(36\%) when compared to other edible vegetables oils (Lin et al. 2013) and animal fat, supporting the CVD associated with SFAs (Monteiro et al., 2017).

There were significant differences on MUFAs (16:1 and 18:1) concentrations between the treatments, as the replacement of animal fat by canola oil gradually reduced 16:1 concentration and increased 18:1 concentration. Visentainer et al. (2015), describes that fatty acid 18:1 (oleic acid) reduces levels of cholesterol and low-density lipoproteins (LDL) in the blood.

An increase in $\Sigma$ MUFAs values was detected as the concentration of canola oil in the product increased. Monteiro et al. (2017), Lee et al. (2015) and Yunes et al. (2013) detected the same behavior when replacing animal fat by vegetable oils, concluding that this approach resulted in a healthier product.

For PUFAs, no significant difference between treatments was detected only for the fatty acid 22:6. For the 18:2 there was a significant difference both by the canola oil \% and the preparation method, where the values decreased as canola oil increased and also increased after coocking (roasted product). For 18:3,

Table 3 - Fatty acids profile of raw and roasted chicken meatballs with different levels of animal fat replacement by canola oil.

\begin{tabular}{|c|c|c|c|c|c|c|c|c|c|c|c|}
\hline \multirow{2}{*}{$\begin{array}{l}\text { Essential fatty } \\
\text { acid (\%) }\end{array}$} & \multicolumn{5}{|c|}{ Canola oil } & \multicolumn{2}{|c|}{ Preparation } & \multirow{2}{*}{ SEM } & \multicolumn{3}{|c|}{$p$ Values } \\
\hline & $0 \%$ & $25 \%$ & $50 \%$ & $75 \%$ & $100 \%$ & raw & roasted & & Canolaoil & Preparation & Interaction \\
\hline C14:0 & 1.08 & 1.33 & 1.37 & 1.15 & 0.93 & 1.31 & 1.03 & 0.07 & 0.26 & 0.06 & 0.46 \\
\hline C 16:0 & $23.06 \mathrm{~A}$ & 19.85B & $16.89 \mathrm{C}$ & 14.59D & $12.23 \mathrm{E}$ & 17.13 & 17.51 & 0.73 & $<0.01$ & 0.33 & 0.79 \\
\hline C18:0 & $6.24 \mathrm{~A}$ & $5.71 \mathrm{~B}$ & $5.29 C$ & $4.86 \mathrm{D}$ & $4.25 \mathrm{E}$ & 5.25 & 5.30 & 0.13 & $<0.01$ & 0.56 & 0.11 \\
\hline$\sum$ SFAs & $30.38 A$ & $26.88 \mathrm{~B}$ & $23.55 \mathrm{C}$ & $20.60 D$ & $17.41 \mathrm{E}$ & 23.69 & 23.84 & 0.86 & $<0.01$ & 0.72 & 0.45 \\
\hline C14:1 & 0.38 & 0.14 & 0.08 & 0.11 & 0.00 & 0.14 & 0.15 & 0.04 & 0.07 & 0.94 & 0.94 \\
\hline C 16:1 & $5.18 \mathrm{~A}$ & $4.15 B$ & $3.20 \mathrm{C}$ & $2.64 C D$ & $2.08 \mathrm{D}$ & 3.41 & 3.49 & 0.21 & $<0.01$ & 0.53 & 0.55 \\
\hline C17:1 & 0.09 & 0.09 & 0.08 & 0.09 & 0.09 & 0.09 & 0.09 & 0.00 & 0.44 & 0.28 & 0.20 \\
\hline C18:1 & $35.80 \mathrm{E}$ & $39.56 \mathrm{D}$ & $43.19 \mathrm{C}$ & $47.64 \mathrm{~B}$ & $50.55 \mathrm{~A}$ & 43.79 & 42.90 & 1.02 & $<0.01$ & 0.08 & 0.46 \\
\hline$\Sigma$ MUFAs & $41.45 \mathrm{E}$ & 43.94D & $46.56 \mathrm{C}$ & $50.48 \mathrm{~B}$ & $52.72 \mathrm{~A}$ & 47.43 & 46.63 & 0.79 & $<0.01$ & 0.06 & 0.37 \\
\hline C18:2 & $24.60 \mathrm{~A}$ & $23.42 B$ & $22.63 B$ & $21.47 C$ & $21.01 \mathrm{C}$ & $22.37 \mathrm{~B}$ & $22.89 \mathrm{~A}$ & 0.26 & $<0.01$ & 0.02 & 0.45 \\
\hline C18:3 & $2.04 \mathrm{E}$ & $3.16 \mathrm{D}$ & $4.32 \mathrm{C}$ & $5.09 B$ & $5.93 \mathrm{~A}$ & 4.13 & 4.08 & 0.27 & $<0.01$ & 0.78 & 0.61 \\
\hline$C 20: 2$ & $0.09 B$ & $0.14 \mathrm{~B}$ & $0.16 \mathrm{~B}$ & $0.11 \mathrm{~B}$ & $0.32 \mathrm{~A}$ & 0.15 & 0.18 & 0.02 & $<0.01$ & 0.09 & 0.51 \\
\hline$C 22: 6$ & 0.00 & 0.03 & 0.02 & 0.02 & 0.03 & 0.01 & 0.02 & 0.00 & 0.07 & 0.25 & 0.66 \\
\hline$\Sigma$ PUFAs & 26.73 & 26.75 & 27.13 & 26.69 & 27.28 & $26.66 \mathrm{~B}$ & $27.17 \mathrm{~A}$ & 0.10 & 0.15 & 0.01 & 0.28 \\
\hline Total fatty acid & $98.55 \mathrm{~A}$ & $97.57 A B$ & $97.24 \mathrm{~B}$ & $97.77 A B$ & $97.42 \mathrm{~B}$ & 97.78 & 97.65 & 0.13 & 0.01 & 0.56 & 0.32 \\
\hline PUFAs/MUFAs & $0.88 \mathrm{D}$ & $0.99 \mathrm{D}$ & $1.15 \mathrm{C}$ & $1.30 \mathrm{~B}$ & $1.58 \mathrm{~A}$ & 1.18 & 1.19 & 0.05 & $<0.01$ & 0.78 & 0.33 \\
\hline n6 & $24.60 \mathrm{~A}$ & $23.42 B$ & $22.63 B$ & $21.47 C$ & $21.00 C$ & $22.36 \mathrm{~B}$ & $22.89 \mathrm{~A}$ & 0.26 & $<0.01$ & 0.02 & 0.45 \\
\hline n3 & $2.04 \mathrm{E}$ & $3.18 \mathrm{D}$ & $4.34 \mathrm{C}$ & $5.10 \mathrm{~B}$ & $5.96 \mathrm{~A}$ & 4.14 & 4.11 & 0.27 & $<0.01$ & 0.82 & 0.60 \\
\hline n6/n3 & $12.20 \mathrm{~A}$ & $7.41 \mathrm{~B}$ & $5.24 C$ & $4.26 C D$ & $3.57 \mathrm{D}$ & 6.48 & 6.59 & 0.59 & $<0.01$ & 0.70 & 0.83 \\
\hline $\begin{array}{l}\text { Atherogenic } \\
\text { index (Al) }\end{array}$ & $0.40 \mathrm{~A}$ & $0.36 \mathrm{~B}$ & $0.30 \mathrm{C}$ & $0.25 \mathrm{D}$ & $0.20 \mathrm{E}$ & 0.31 & 0.30 & 0.01 & $<0.01$ & 0.36 & 0.33 \\
\hline $\begin{array}{l}\text { Thrombogenic } \\
\text { index (TI) }\end{array}$ & $0.59 \mathrm{~A}$ & $0.53 B$ & $0.45 \mathrm{C}$ & $0.37 \mathrm{D}$ & $0.30 \mathrm{E}$ & 0.45 & 0.45 & 0.02 & $<0.01$ & 0.76 & 0.49 \\
\hline
\end{tabular}

SFAs = saturated fatty acids; MUFAs = monounsaturated fatty acids; PUFAs = polyunsaturated fatty acids.

$\mathrm{Al}=((\mathrm{C} 12: 0)+4(\mathrm{C} 14: 0)+(\mathrm{C} 16: 0)) /((\mathrm{n} 6)+(\mathrm{n3})+((\mathrm{MUFAs}))$

$\mathrm{TI}=((\mathrm{C} 14: 0)+(\mathrm{C} 16: 0)+(\mathrm{C} 18: 0) /(0.5(\Sigma$ MUFAs $)+0.5(\mathrm{n} 6)+3(\mathrm{n} 3)+(\mathrm{n} 3 / \mathrm{n} 6))$

Means followed by the same letter, within each factor, are not different by Tukey test $(p<0.05)$. 
there was a significant increase in the values as the replacement of animal fat by canola oil occurred. The explanation for the correlation between a decrease in fat animal $18: 2$ and the increase in $18: 3$ is due to the fact that it has a low percentage of $18: 3(1.3 \%)$, whereas the canola oil contains higher concentrations (9.3\%) (Martin et al.; Chiu et al., 2008).

For the $\Sigma$ PUFAs there was only the significant difference between the preparation methods, where the values increased after the roasting. The difference between the treatments in the $\Sigma$ PUFAs in the present work was not verified due to the low percentage of lipid added to the meatballs ( $2.8 \%$ of the total mass of the product), which was insufficient so that the difference between the animal fat and the substituent, canola oil expressed significant difference. Monteiro et al. (2017) and Yunes et al. (2013) found an increase in the values of $\Sigma$ PUFAs in their respective studies when they replaced animal fat with canola oil in meat products. The different result presented by these authors is related to a greater proportion of the substituted lipid component in relation to the present study.

The sum of the total fatty acid and the PUFAs/SFAs ratio presented a significant difference $(p<0.05)$. The increase in the PUFAs/ SFAs ratio occurred from the substitution of $50 \%$ canola oil since this oil is rich in PUFAs (Eskin \& McDonald, 1991; Lin et al., 2013). Muguerza, Ansorena and Astiasarán (2003) and Özvural \& Vural (2008), also found this relationship in their studies where they replaced vegetable oils by animal fat in meat products, obtaining an increase in nutritional benefit, since SFAs are associated with CVD.

A significant increase $(p<0.05)$ in the amount of fatty acid $n 3$ and a reduction of $n 6$ was observed. The n6 also showed a significant difference $(p<0.05)$ in the preparation method, where the values increased in the roasted meatballs. These values are associated with the values found for 18: 2 and 18: 3, since the calculation of $n 3$ and $n 6$ is the sum of the fatty acid found.

The $n 6 / n 3$ ratio significantly decreased from 12.20 to 3.57. This reason is important for reducing the risk of CVD, diabetes and cancer. Romero et al. (2013) Manhezi, Bachion, and Pereira (2008) have cited that high values of this ratio promoted the pathogenesis of many diseases, including cancer, cardiovascular disease, autoimmune and inflammatory diseases. Visentainer et al. (2015) cited that the ideal ratio of n6/n3 for good health is $1: 1$ to $4: 1$.

In relation to $\mathrm{Al}$ and $\mathrm{TI}$, there was a significant difference in both, where the values obtained decreased accordingly to animal fat substitution. Monteiro et al. (2017) also reported this decrease in $\mathrm{IA}$ and $\mathrm{TI}$ in his work. IA and TI are good indicators of the dietary potential to induce atherosclerosis and thrombosis, signs associated with the establishment of CVD (Santos et al., 2013).

In view of the obtained data, it is identified that the substitution of animal fat by canola oil improved the fatty acid profile of the elaborated product by significantly reducing the levels of SFAs, $\mathrm{Al}, \mathrm{TI}$ and significantly increasing MUFAs levels and PUFAs/SFAs ratio. Regarding $\mathrm{n} 6 / \mathrm{n} 3$ ratio, it was observed that the best substitution levels were $75 \%$ and $100 \%$, maintaining a balance of the EFAs in the diet.

\section{Shelf life}

The results are presented in Table 4. There was no significant interaction between canola oil \% and time for the Aw variable and $a^{*}$ and $b$ * color parameters. Interaction between the factors was observed in the variables textures, Tbars and $L^{*}$ color parameters.

The $\mathrm{pH}$ variable was considered non-parametric, therefore the interaction between canola oil \% and time was not evaluated. There was a significant effect $(p<0.05)$ on the time factor. Verma et al. (2016) and Yunes et al. (2013) reported that $\mathrm{pH}$ increases significantly as the storage time grows. This increase, according to Jay (1996), is associated with the presence of basic compounds resulting from the decarboxylation reaction and deamination of some amino acids by the enzymes present in the meat. Thus, the increase of $\mathrm{pH}$ may be correlated with the production of these compounds and subsequent exhaustion of them, causing the values to fall.

The variable Aw presented a significant difference $(p<0.05)$ between the meatballs with $100 \%$ substitution of canola for the other substitutions. Despite this difference, the levels found were not important for the sensory or conservation characteristics of the food.

This variable also showed a significant difference $(p<0.05)$ in the time factor. There is a reduction between the time 90 and 120 days for the others. Backes et al. (2013) attributed the decrease in the $\mathrm{pH}$ found with the water retention capacity of the proteins, which is affected when the $\mathrm{pH}$ of the product approaches the isoelectric point (5.3), leading to dehydration of the product, $\mathrm{pH}$ near the isoelectric point is directly correlated with the Aw reduction of the product.

Backes et al. (2013) described that the amount of water in the product is one of the main factors responsible for the texture. However, this correlation 
Table 4 - Shelf life parameters of chicken meatballs with different levels of animal fat replacement by canola oil and frozen stored for 120 days.

\begin{tabular}{|c|c|c|c|c|c|c|c|}
\hline Factors & Aw & $\mathrm{pH}$ & Tbars (mg) & Texture $(\mathrm{kgf} / \mathrm{mm})$ & Color L* & Color a* & ColorB* \\
\hline \multicolumn{8}{|c|}{ canola oil(\%) } \\
\hline 0 & $0.98 \mathrm{~A}$ & 5.93 & 1.11 & 2.30 & 67.92 & 3.19 & 21.81 \\
\hline 25 & $0.98 A B$ & 5.97 & 1.02 & 2.27 & 66.03 & 3.28 & 21.77 \\
\hline 50 & $0.98 \mathrm{AB}$ & 6.00 & 1.06 & 2.29 & 66.50 & 3.28 & 22.42 \\
\hline 75 & $0.98 \mathrm{AB}$ & 5.99 & 1.08 & 2.23 & 66.86 & 3.07 & 21.85 \\
\hline 100 & $0.97 \mathrm{~B}$ & 5.95 & 0.93 & 2.06 & 66.93 & 3.27 & 22.25 \\
\hline \multicolumn{8}{|l|}{ time (days) } \\
\hline 0 & $0.98 \mathrm{~A}$ & $5.97 B C$ & 0.95 & 2.03 & 69.17 & $2.57 \mathrm{~B}$ & $21.24 \mathrm{D}$ \\
\hline 30 & $0.98 \mathrm{~B}$ & $6.20 \mathrm{~A}$ & 0.80 & 2.91 & 70.15 & $2.78 \mathrm{~B}$ & $22.12 B C$ \\
\hline 60 & $0.98 \mathrm{AB}$ & $6.05 A B$ & 1.24 & 2.18 & 69.95 & $2.57 \mathrm{~B}$ & $21.28 C D$ \\
\hline 90 & $0.97 C$ & $5.86 C D$ & 1.05 & 2.11 & 57.05 & $4.19 \mathrm{~A}$ & $23.25 \mathrm{~A}$ \\
\hline 120 & $0.97 C$ & $5.77 \mathrm{D}$ & 1.17 & 1.91 & 67.92 & $3.99 \mathrm{~A}$ & $22.21 \mathrm{~B}$ \\
\hline SEM & $<0.01$ & 0.02 & 0.02 & 0.05 & 0.62 & 0.10 & 0.01 \\
\hline \multicolumn{8}{|l|}{$p$ values } \\
\hline canolaoil & 0.03 & 0.77 & $<0.01$ & 0.04 & 0.05 & 0.71 & 0.15 \\
\hline time & $<0.01$ & $<0.01$ & $<0.01$ & $<0.01$ & $<0.01$ & $<0.01$ & $<0.01$ \\
\hline interaction & 0.08 & -1 & $<0.01$ & $<0.01$ & 0.04 & 0.86 & 0.47 \\
\hline
\end{tabular}

Aw = water activity.

Aw, pH and Tbars were analyzed in raw products; texture and color in roasted products.

${ }^{1} \mathrm{pH}$ was analyzed in a non-parametric manner thus interaction between factors did not enter the statistical model.

Significant interactions are presented in Tables 5, 6 and 7.

Means followed by the same letter, within each factor, are not different by Tukey test $(p<0.05)$.

was not found in the interaction found in the study (Table 5), where the best observed value of this interaction was at 30 days for all different concentrations of canola oil.

Hsu \& Chung (1998) described that texture can be influenced by lipid, in addition to the preparation methodology of the product which is also an important factor, since the temperature and the methodology employed can affect the stability of lipids and their solubility. Animal fat and canola oil can influence the lipid oxidation of a product, which can cause food rancification during storage. Thus, lipid oxidation is a very important factor for the quality of the food, especially in products with a high PUFAs content such as poultry meat and canola oil (Nurkhoeriyati et al., 2012; Karpińska-tymoszczyk, 2013; McDonald, 1991). In this sense, the Tbars test is a widely used test for the evaluation of lipid oxidation of products. During lipid peroxidation, aldehyde, ketone and other fatty acid degradation compounds are generated. The concentration of these compounds is usually expressed as amount of free malonaldehyde (MDA) (Karpińska-tymoszczyk, 2013).

Table 5 - Interaction between canola oil and storage time on the texture of raw chicken meatballs.

\begin{tabular}{lccccc}
\hline & \multicolumn{5}{c}{ Time (days) } \\
\cline { 2 - 6 } Canola oil & 0 & 30 & 60 & 90 & 120 \\
\hline $0 \%$ & $2.23 \mathrm{Ba}$ & $2.76 \mathrm{Aa}$ & $2.26 \mathrm{Bab}$ & $2.53 \mathrm{ABa}$ & $1.7 \mathrm{Cb}$ \\
$25 \%$ & $1.95 \mathrm{Bab}$ & $3.06 \mathrm{Aa}$ & $2.04 \mathrm{Bb}$ & $2.22 \mathrm{Ba}$ & $2.1 \mathrm{Ba}$ \\
$50 \%$ & $2.00 \mathrm{Bab}$ & $3.09 \mathrm{Aa}$ & $2.11 \mathrm{Bb}$ & $2.24 \mathrm{Ba}$ & $1.98 \mathrm{Bab}$ \\
$75 \%$ & $2.18 \mathrm{BCab}$ & $2.78 \mathrm{Aa}$ & $2.50 \mathrm{ABa}$ & $1.76 \mathrm{Db}$ & $1.95 \mathrm{CDab}$ \\
$100 \%$ & $1.81 \mathrm{Bb}$ & $2.86 \mathrm{Aa}$ & $2.00 \mathrm{Bb}$ & $1.79 \mathrm{Bb}$ & $1.82 \mathrm{Bab}$ \\
\hline
\end{tabular}

Means followed by the same uppercase letter (row), or same lowercase letter (column)are not different by Tukey test $(p<0.05)$.

An interaction between time and canola oil \% was observed for MDA (Table 6). During the storage time, the rate of lipid oxidation in meatballs at days 0 , and 120 had a significant difference $(p<0.05)$. The highest MDA index was detected at day 60 and later there was a downward trend, indicating the onset and regression of lipid oxidation in chicken meatballs. Karpińska-Tymoszczyk (2013) also identified this variation in storage time of frozen cooked turkey meatballs. Gokalp et al. (1983) and Kuo et al. (1987) explain that, during storage, malonaldehyde, which is an intermediate by-product formed in the lipid 
Table 6 - Interaction between canola oil and storage time on the Tbars of raw chicken meatballs.

\begin{tabular}{llllll}
\hline \multirow{2}{*}{ Canola oil } & Time (days) & & & \\
\cline { 2 - 6 } & 0 & $0.89 \mathrm{Ca}$ & $1.31 \mathrm{Aa}$ & $1.12 \mathrm{Ba}$ & 120 \\
\hline $0 \%$ & $0.96 \mathrm{Cb}$ & $0.73 \mathrm{Db}$ & $1.16 \mathrm{ABb}$ & $1.08 \mathrm{Ba}$ & $1.35 \mathrm{Aa}$ \\
$25 \%$ & $0.92 \mathrm{Cb}$ & $0.78 \mathrm{Db}$ & $1.33 \mathrm{Aa}$ & $1.08 \mathrm{BCa}$ & $1.23 \mathrm{Ab}$ \\
$50 \%$ & $0.99 \mathrm{Cb}$ & $0.87 \mathrm{Ca}$ & $1.27 \mathrm{Aa}$ & $1.07 \mathrm{Ba}$ & $1.09 \mathrm{BC}$ \\
$75 \%$ & $1.1 \mathrm{Ba}$ & $0.71 \mathrm{Cb}$ & $1.15 \mathrm{Ab}$ & $0.9 \mathrm{Bb}$ & $1.09 \mathrm{Ac}$ \\
\hline
\end{tabular}

Means followed by the same uppercase letter (row), or same lowercase letter (column) are not different by Tukey test $(p<0.05)$.

oxidation termination phase, may be oxidized to other organic acids and alcohols which cannot react with the TBA indicator agent. Ahamed et al. (2007) attributed the reduction of Tbars in long-term storage products to the MDA reaction in proteins, aminoacids and phospholipids. Also, Racanicci et al. (2004) described that the MDA content decreases when the rate of carbonylation with proteins becomes higher than the rate of Tbars formation. Nurkhoeriyati, Huda \& Ahmad (2012) cite that some authors describe that MDA and other short chain carbon compounds are unstable and probably decompose into alcohols and organic acids, which are not detected by the TBA test. In relation to the concentrations of canola oil, the highest MDA index was observed in the concentrations with higher amounts of animal fat, probably because the citric acid contained in the commercial canola oil used here acted as antioxidants, helping to delay the lipid oxidation process. Because it is a natural compound, citric acid has been widely used as stabilizers in various products, including vegetable oils (Kubicek, Rohr, Rehm, 1985).

In the present study, the parameters of color a* (red-green) and $b^{*}$ (yellow-blue) showed an increase in their values with time after 90 days of storage (Table 7). Fernández-López et al. (2005) described that the oxidative process in meat and meat products lead to the degradation of lipids and proteins, which in turn contribute to the alteration of texture and color of exposed meat products. AMSA (2016) mentioned that oscillations in color parameter values may occur because the denaturation of myoglobin is not constant.

For the parameter $L^{*}$ (brightness) there was interaction between the time and the different

Table 7 - Interaction between canola oil and storage time on the color $\mathrm{L}^{*}$ parameter of raw chicken meatballs.

\begin{tabular}{lccccc}
\hline \multirow{2}{*}{ Canola } & \multicolumn{5}{c}{ Time (days) } \\
\cline { 2 - 5 } & 0 & 30 & 60 & 90 & 120 \\
\hline $0 \%$ & $69.8 \mathrm{Aa}$ & $70.89 \mathrm{Aa}$ & $70.68 \mathrm{Aa}$ & $59.17 \mathrm{Ba}$ & $69.06 \mathrm{Aa}$ \\
$25 \%$ & $69.5 \mathrm{ABa}$ & $70.51 \mathrm{Aa}$ & $70.14 \mathrm{ABa}$ & $52.57 \mathrm{Cc}$ & $67.45 \mathrm{Ba}$ \\
$50 \%$ & $68.99 \mathrm{Aa}$ & $69.20 \mathrm{Aa}$ & $70.00 \mathrm{Aa}$ & $56.27 \mathrm{Bb}$ & $68.06 \mathrm{Aa}$ \\
$75 \%$ & $68.79 \mathrm{ABa}$ & $70.80 \mathrm{Aa}$ & $69.84 \mathrm{ABa}$ & $57.72 \mathrm{Cab}$ & $67.16 \mathrm{Ba}$ \\
$100 \%$ & $68.77 \mathrm{Aa}$ & $69.00 \mathrm{Aa}$ & $69.10 \mathrm{Aa}$ & $59.53 \mathrm{Ba}$ & $67.00 \mathrm{Aa}$ \\
\hline
\end{tabular}

Means followed by the same uppercase letter (row), or same lowercase letter (column) are not different by Tukey test $(p<0.05)$.

canola oil \% (Table 8). The levels of 0, 50 and 100\% replacement presented the same behavior during the 120 days, demonstrating that there was no difference between the substitution levels and the storage time.
The averages found in the color parameters showed a product with yellow coloration, with low values of red and high luminosity. These findings may have been influenced by the raw material used, chicken meat and fat, which contains low amounts of myoglobin (Yilmaz,

Table $\mathbf{8}$ - Sensory analysis of chicken meatballs with different levels of animal fat replacement by canola oil.

\begin{tabular}{|c|c|c|c|c|c|c|c|}
\hline \multirow{2}{*}{ Item } & \multicolumn{5}{|c|}{ Canolaoil } & \multirow[b]{2}{*}{ SEM } & \multirow[b]{2}{*}{$P$ values } \\
\hline & $0 \%$ & $25 \%$ & $50 \%$ & $75 \%$ & $100 \%$ & & \\
\hline odor & 6.88 & 7.12 & 6.93 & 7.22 & 7.01 & 0.07 & 0.74 \\
\hline color & 6.71 & 6.62 & 6.87 & 6.76 & 6.64 & 0.07 & 0.76 \\
\hline appearance & 6.90 & 7.02 & 6.80 & 6.87 & 6.66 & 0.07 & 0.64 \\
\hline texture & 6.96 & 7.36 & 7.25 & 7.18 & 6.92 & 0.07 & 0.38 \\
\hline flavor & 7.24 & 7.62 & 6.94 & 7.36 & 7.41 & 0.07 & 0.10 \\
\hline acceptability index (\%) & 77.00 & 79.44 & 78.88 & 78.66 & 76.00 & - & - \\
\hline
\end{tabular}

With the exception of the acceptability index, the other variables express the average concept obtained from 80 evaluators, in a scale from 1 (highly disliked) to 9 (liked it very much). 
Isikl, Simsek, 2002) and canola oil itself, which are products of yellowish coloration and high luminosity.

\section{Sensory analysis}

Animal fat substitution did not influence metabolic smell, color, appearance, texture and taste in the time zero (Table 8). As there was substitution of only one type of lipid for another, contributing to the fact that there was no difference in the characteristics of the original product without the canola oil. In addition, the acceptability values showed that all products met the general assumptions for marketing (higher than 70\%) (Zenebon, Pascuet, Tiglea, 2008). Therefore, there is no reason to suspect that the replacement of animal fat by canola oil alters the sensory characteristics of the product when we consider time zero of storage.

\section{CONCLUSIONS}

The replacement of animal fat by canola oil in chicken meatballs proved to be a viable alternative to produce a healthier product, since it achieved the objectives of improving the fatty acid profile of the product by reducing SFAs, IA and TI increasing unsaturated fatty acids and PUFAs/SFAs ratio and improving $n 6 / n 3$ ratio, without significantly altering the characteristics of centesimal and shelf life traits and, especially, without changing the sensory characteristics of the product.

The replacement of animal fat by canola oil in chicken meatballs proved to be a viable alternative to improve the nutritional characteristics of the product, since the technology employed reached the objectives of improving the fatty acid profile of the product through the reduction of saturated fatty acids, atherogenic and thrombogenic indexes, increase of the unsaturated fatty acids, PUFA/MUFA ratio and improvement in the $n 6 / n 3$ ratio, without significantly altering the composition and shelf life characteristics and without altering the sensorial characteristics of the product. Animal fat can be completely replaced by canola oil in the chicken meatballs, since not even the total replacement of animal fat by canola oil in the product, caused changes in texture, color parameters and oxidation that could be related to addition of the canola oil and the sensorial analysis confirmed the acceptance, proving the results of this research, the feasibility and importance of the substitution of animal fat by canola oil in chicken meatballs.

\section{ACKNOWLEDGMENTS}

To the College of Technology of SENAI Mato Grosso for granting part of the laboratory facilities used in this study and to CAPES/Brazil for granting the Master's scholarship of the first author.

\section{REFERENCES}

Afshari R, Hosseini H, Mousavi AK, Khaksar R. Physico-chemical properties of functional low-fat beef burgers:fatty acid profile modification. LWT - Food Science and Technology 2017;78:325-331.

Ahamed ME, Anjaneyulu ASR, Thomas R, Kondaiah N. Effect of enrobing on the quality and shelf life of buffalo meat cutlets under frozen storage. Journal of Muscle Foods 2007;18:19-34.

AMSA - American Meat Science Association - Research guidelines for cookery, sensory evaluation, and instrumental tenderness measurements of fresh meat. $2^{\text {nd }}$ ed. Champaign: Meat Science Org; 2016.

AOAC - Association of Official Analytical Chemists. Official methods of analysis. $19^{\text {th }}$ ed. Maryland: AOAC International; 2012

Backes AM, Terra NN, Guidolin LI, Rezer APS, Lüdtke FL, Cavalheiro CP, et al. Características físico-químicas e aceitação sensorial de salame tipo italiano com adição de óleo de canola. Semina Ciências Agrárias 2013;34:3709-3720.

Barbut S, Marangoni A. Organogels use in meat processing - effects of fat/ oil type and heating rate. Meat Science 2019;149:9-13.

Brasil. Ministério da Saúde - Agência Nacional de Vigilância Sanitária. Resolução n¹2, de 02 de janeiro de 2001. Regulamento técnico relativo a padrões microbiológicos para alimentos. Brasília: Diário Oficial da União da República Federativa do Brasil; 2001. 67 p.

Chiu MC, Gioielli LA, Grimaldi R. Lipídios estruturados obtidos a partir da mistura de gordura de frango, sua estearina e triacilgliceróis de cadeia média:I -composição em ácidos graxos e em triacilgliceróis. Química Nova 2008;31:232-237.

Eskin NAM, Mcdonald BE. Canola oil. Nutrition Bulletin 1991;16:138-146.

Fernández-López J, Zhi N, Aleson-Carbonell L, Pérez-Alvarez JA, Kuri V. Antioxidant and antibacterial activities of natural extracts:application in beef meatballs. Meat Science 2005;69:371-380.

Folch J, Lees M, Stanley GMS. A simple method for the isolation and purification of total lipids. Journal of Biological Chemistry 1957;226:497-509.

Gokalp HY, Ockerman HW, Plimpton RF, Harper WP. Fatty acids of neutra and phospholipids, rancidity scores and tba values as influenced by packaging and storage. Journal of Food Science 1983;48:829-834.

Hartman L, Lago RCA. Rapid preparation of fatty acids methyl esters. Laboratory Practice 1973;22:475-476.

Hsu SY, Chung HY. Effects of processing factors on qualities of emulsified meatball. Journal of Food Engineering 1998;36:337-347.

International Commission on Microbiological Specifications for Foods. Microorganisms in foods. sampling for microbiological analysis: principles and specific applications. $2^{\text {nd }}$ ed. Toronto: Universityof Toronto; $1986.131 \mathrm{p}$.

Jay JM. Microbiologia de alimentos. $4^{\text {th }}$ ed. New Delhi: Artmed; 1996. 712 p.

Karpińska-Tymoszczyk M. The effect of oil-soluble rosemary extract, sodium erythorbate, their mixture, and packaging method on the quality of turkey meatballs. Journal of Food Science and Technology 2013;50:443-454. 
Kubicek CP, Rohr M, Rehm HJ. Citric acid fermentation. CRC Critical Review in Biotechnology 1985;3:331-373.

Kuo JC, Dresel J, Huang CJ, Ockerman HW. Effect of phosphate type, packaging method and storage time on characteristics of Chinese sausage. Journal of Food Processing and Preservation 1987;11:325338.

Lee $\mathrm{H}$, Jung E, Lee S, Kim J, Lee J, Choi Y. Effect of replacing pork fat with vegetable oils on quality properties of emulsion-type pork sausages. Korean Journal of Food Science and Animal Resource 2015;35:130136.

Lin L, Allemekinders H, Dansby A, Campbell L, Durance-Tod S, Berger A , et al. Evidence of health benefits of canola oil. Nutrition Reviews 2013;71:370-385.

Martin CA, Almeida VV, Ruiz MR, Visentainer JEL, Matshushita M, Souza NE, et al. Ácidos graxos poli-insaturados ômega 3 e ômega 6:importância no metabolismo e na nutrição. Revista Nutrição 2006;19:761-770.

Monteiro GM, Souza XR, Costa DPB, Faria PB, Vicente J. Partial substitution of pork fat with canola oil in toscana sausage. Innovative Food Science \& Emerging Technologies 2017;44:2-8.

Nurkhoeriyati T, Huda N, Ahmad R. Physicochemical properties and sensory analysis of duck meatballs containing duck meat surimi-like material during frozen storage. Journal of Food Science 2012;77:s91-s98.

Ozvural EB, Vural $\mathrm{H}$. Utilization of interesterified oil blends in the production of frankfurters. Meat Science 2008;78:211-216.
Racanicci AMC, Danielsen B, Menten JFM, Regitano-d'Arce MAB, Skibsted LH. Lipid oxidation decreases metabolizable energy value of dietary poultry fat for growing broilers. Revista Brasileira de Zootecnia 2004;33:919-923.

Santos RD, Gagliardi ACM, Xavier HT, Magnoni CD, Cassani R, Lottenberg AMI. Diretriz sobre o consumo degorduras e saúde vascular. Revista da Sociedade Brasileira de Cardiologia 2013;100:1-40.

Ulbricht TL, Southgate DA. Coronary heart disease: seven dietary factors. Lancet 1991;338:985-992.

Verma AK, Pathak V, Singh VP, Umaraw P. Storage study of chicken meatballs incorporated with green cabbage (Brassica olerecea) at refrigeration temperature $\left(4 \pm 1^{\circ} \mathrm{C}\right)$ under aerobic packaging. Journal of Applied Animal Research 2016;44:409-414.

Visentainer JV, Biondo PBF, Petenuci ME, Claus T, Montanher PF, Santos Junior OO. Canola: a química analítica do processamento aos compostos bioativos. Curitiba: Appris; 2015. 107p.

Yilmaz I, Isikli M, Simsek O. Fatty acid composition and quality characteristics of low-fat cooked sausages made with beef and chicken meat, tomato juice and sunflower oil. Meat Science 2002;62:253-258.

Yunes FF, Terral NN, Cavalheiro CP, Fries LLM, Godoyl HT, Ballus CA. Perfil de ácidos graxos e teor de colesterol de mortadela elaborada com óleos vegetais. Ciência Rural 2013;43:924-929.

Zenebon O, Pascuet NS, Tiglea P. Métodos físico-químicos para análise de alimentos. $4^{\mathrm{a}}$ ed. São Paulo: Instituto Adolfo Lutz; 2008. p.279-320. 
